\title{
Correction to: Decolonising Blue Spaces in the Anthropocene
}

\section{Correction to:}

M. Parsons et al., Decolonising Blue Spaces in the Anthropocene, Palgrave Studies in Natural Resource Management, https://doi.org/10.1007/978-3-030-61071-5

This book was inadvertently published with incorrect information with reference to The Waikato River Authority on pages 306, 307, 369 and 370. This text has now been revised and updated.

The updated version of these chapters can be found at https://doi.org/10.1007/978-3-030-61071-5_7

https://doi.org/10.1007/978-3-030-61071-5_9 